\title{
THE GROWTH OF THE CITIES OF WASHINGTON
}

\author{
By W. M. Gregory* \\ Normal School, Cleveland, Ohio
}

$66 \mathrm{~W}$ HY, I would not give a pinch of snuff for the whole country! Do you think your honest farmers of Pennsylvania, New York, Ohio, Illinois or Missouri will leave their farms and go on such an enterprise as this?" This is the statement of United States Senator McDuffie in 1843 when the Oregon Bill was passed in the Senate by a narrow margin. After its passage Daniel Webster, then Secretary of State, deemed the Puget Sound region of such slight value that it was nearly lost in the Oregon Treaty Negotiations of 1846 .

The falsity of these short sighted visions has been fully shown by the subsequent amazing economic developments of the Northwest, making its present per capita wealth twice that of Ohio, Michigan, or Wisconsin. It is true that the first settlement in 1825 at Fort Vancouver on the Columbia River was a remote trading post of the Hudson Bay Fur Trading Company. It was fur that Captain Gray sought when he established a lonely station on Grays Harbor. The beaver skin was then valuable for hats but a change in London's fashions brought in the silk hat and with the natural decrease in demand for the beaver skin, the interest of the Hudson Bay Fur Company in this region gradually waned. It was a natural step from the fur to the fish of Puget Sound, and Doctor Manyard in 1852, one of the earliest settlers of Seattle, sought land along with the Denny family for a salmon packing plant. Along with these workers came one Yesler who built a saw mill near the fish packing shanty, thus the community started early in the progressive development of its natural resources.

The north to south extent of the Cascade Mountains through the center of the state was the barrier that determined the settlement of its eastern portion first. This was accomplished by Marcus Whitman in 1836 who established an Indian Mission at Walla Walla where he tilled the soil and first taught the natives how to irrigate the crops. On the western slope of the mountains the first settlements were along the edge of Puget Sound as it offered fine opportunities for trading and fishing. The first settlers on the Sound gathered at Tumwater, near the present site of Olympia, in 1844, and they at once harnessed the small stream for a combined grist mill and sawmill.

The real peopling of Washington was started by the Oregon Migration in the spring of 1843 . This party, of more than one thousand people from Ohio, Indiana, Michigan, and other honest farmers of the middle west, had Marcus Whitman as one of the leaders and followed the Oregon Trail through the South Pass into the new country. Horace Greeley considered

*Mr. Gregory was a member of Summer School faculty of the University of Washington in 1915. 
these people wholly insane but he lived to visit this region of marvelous possibilities and advised young men to go west.

The long caravans crawling slowly over the plains and the mountains did not bring the people very rapidly for in 1853 the total population was slightly less than four thousand and the native Indians numbered nearly six times the scattered groups of whites. The early comers spread over the new lands, selecting those sites that were best adapted for fishing, sawmills and trading posts.

\section{RAPID DeVelopment}

Following this period of small struggling centers of industry came a rapid and a tremendous development when the great timber resources were suddenly made accessible by the railroads that were extended into this region with marvelous rapidity. One of the earliest rail roads was at Walla Walla in 1876 , its rails were wooden stringers covered with rawhide. Its traffic was frequently delayed by the starving coyotes eating the hide track. which is a minor incident in the rapid railroad development that enabled the state to jump from the difficult trail and the slow caravan to the more expeditious steam road. In 1880 Washington had less than three hundred miles of railroad and in the decade that followed its mileage increased ten times and the same period had an increase of 375 per cent in population. These decades of wonderful growth in population were due to the sudden opening of the vast forests to lumbering. The railroad found a ready market in the east or at a shipping port on the coast for the lumber, the salmon, and the wheat. The western terminus of each road became a port for the outlet of the regions of production. Thus the gathering points for manufacture or for shipping were the places that had the greatest growth in the early development of the state's natural resources. At present more than one half of the people are living in manufacturing or shipping communities of three thousand or more inhabitants. Washington has leaped from an undeveloped region of scattered sawmills and fishing ports to an urban state in which its percentage of urban people ranks eleventh among the states. The wagon road stage of development that stands in the growth of a community between the trail and the steam road was rapidly hurdled. Hence the rural life has developed slowly and at present only one quarter of the state is in farm land, for the exploitation of the forests has offered a more rapid source of wealth than the slower process of soil cultivation.

\section{Importance of Puget Sound}

In the vigorous growth of the cities of the western part of the state the forests and the railroads have been controlling influences to which must be added the geographical advantage of their location on the salt water estuary of Puget Sound. This Inland Sea of the Northwest reaches nearly one hundred miles eastward with its narrow arms of deep navigable water that extend into the lands for more than a hundred miles to the north and south. This "Har- 
bour Country" offers to commerce more than 1,900 miles of shore line, many deep and easily accessible harbors surrounded by a land of equable climate. Further, this body of water is nearer Chicago, Alaska and Japan than is the rival harbor of San Francisco, and this is a great geographic advantage for Puget Sound in the competition for Pacific commerce.

It is about Puget Sound that the most vigorous growth of cities has taken place. The counties contiguous to Puget Sound are about one fifth of the area of the state and yet they have more than one half of its total population. The railroads reaching westward to this Inland Sea have made cities where they touch the open and navigable water of the Sound. The growth and development of these railroad and port towns has been due at first to the lumber, then to the fish, and later to the rich resources of Alaska and the extensive markets of the Far East. The materials and outfits for the Alaskan development have been shipped largely from the Puget Sound ports and in return they have controlled the Alaskan products. In the Far East markets the Puget Sound ports show their advantage in distance by their greater imports of raw silk and far greater shipments of iron products than San Francisco.

\section{Seattle}

Seattle is the first city of the Northwest because it has the most advantageous site on Puget Sound for the union of sea commerce and land trade. Seattle owes its growth more to its commercial interests than to the development of its nearby resources of coal, water power, and timber. John Holgate was the sole inhabitant in 1850 ; the Denny party came in 1851 and when a few months later Yesler started a saw mill, Seattle gave promise of being a typical "sawdust and salmon", town. Twenty years later it had about one thousand people who had increased the number of saw mills and fishing shacks that were scattered among the piles of logs and lumber.

The builders of the railroads to the westward discovered (about 1884) that Seattle's site, midway on the eastern edge of Puget Sound on a nearly straight channel to the ocean, was the strategic point for railroads to meet the deep sea navigation. Seattle is on a narrow peninsula between Lake Washington (fresh water) and the salt water of Puget Sound. The city has grown about Elliott Bay, along whose edge are the great navigation docks and the various railroad terminals. Entering Elliott Bay from the south is the Duwamish River, the tidal flats of which have been improved by dredging and filling, so that the two distributaries of the river are now known as the East and West Waterways and form commercial assets of great future value. North on this deep bay is Smith Cove where the largest steamship docks have been constructed. Exten'ding through the northern portion of the city is still another addition to its commercial advantages-the long, narrow Salmon Bay, Lake Union and the Government ship canal that connects Union Bay, an arm of Lake Washington, with Lake Union and thus with the Sound. The area of the city that has been developed under these favorable conditions is some 
fifty-eight square miles of land, while its lake and rivers are some eleven square miles and the salt-water about twenty-four square miles in addition. The land rises sudidenly from the water's edge and in places like Magnolia Bluff the steep banks are very near the shore. The surface is one of rolling drumloidal hills with the longer axes generally north and south. The hills rise three to four hundred feet above the water and their summits are fine residential sites but they were such a disadvantage in the business section that they were removed in a true western fashion. The loose gravels and clays made it an easy task to use hydraulic streams to remove enormous quantities of the earth and in places a depth of more than eighty-five feet was removed to make the sixty miles of level streets required in the business section.

Seattle's growth was slow at first. Its trade was chiefly lumber and fish, but the coming of the railroad in 1884 was the initiation of a period of astonishing growth. In the twenty years from 1880 the city grew from three thousand to over eighty thousand. This was a time of the opening of one new field after another. First it was lumber and fish, then Alaska and the Far East trade. In 1896, with the discovery of gold in Alaska and the feverish rushes to the Klondike in 1897 , followed by the opening of the Nome and Fairbanks region, Seattle's position gave it almost a monopoly in their trade. It was the logical outfitting center and likewise the port of entry for the gold, furs, and fish of the new lands.

The Far East trade for Seattle began about 1896 with the establishment of a steamship line to the Orient. Seattle holds first rank on the Pacific Coast in foreign imports of raw silk, tea, and fiber, while it exports canned fish, ironware, lumber, and coal. The foreign trade has grown from 15 million to 56 million dollars (1914). The domestic trade for 1914 was nearly 50 million dollars, one third of which was Alaskan. The building of railroads in Alaska will further stimulate this trade and the Panama Canal is furnishing a more direct and cheaper shipping route for products from Seattle.

Seattle's chief asset is its harbor; it is a typical port city and young as it is, ranks sixth among the ports of this country. Its advantageous position, at the "break in transportation" on the shortest trade line between our eastern states and the countries of the Orient and Alaska, has been the controlling factor in its development. The following table is an attempt to give definite value to the various influences that have been contributing factors in Seattle's growth:

1. Commercial resources of its tributary lands $\ldots \ldots \ldots \ldots \ldots \ldots 20$

(Alaska, Far East and the Puget Sound region)

2. Water transportation and ample dockage............... 15

(Deep water harbor and municipal docks)

3. Geographical location and advantages of shorter routes........ 15

(Strategic trade point on Puget Sound and on the shortest line

between the Orient and the Eastern States) 
4. Railroad connections and seven competing lines $\ldots \ldots \ldots \ldots \ldots 13$

5. Climatic conditions of fogs, winds and temperatures......... 10

6. Character of citizens-"The Seattle Spirit".............. 8

7. Topography and future area for expansion of trade and shipping.... 7

8. Age of city and surrounding country $\ldots \ldots \ldots \ldots \ldots \ldots \ldots \ldots$

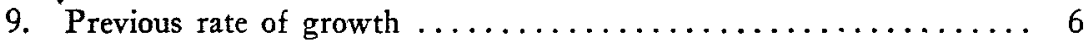

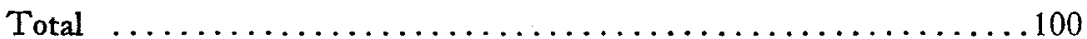

Seattle is a young city that has about passed its period of most vigorous growth and its future increase will be slower. It is more than possible that the present time is one of those halts that frequently occur in cities that have had a very recent vigorous growth. In 1910 Seattle was the twenty-first city in population and in an estimate issued in July, 1915, it was ranked as the nineteenth city. This was based entirely upon the rate of increase previous to 1910 which the writer believes is much too high for the present times.

\section{SPOKANE}

Spokane, the second city of the state, began with a saw-mill and three men in 1872. The Indians regarded the falls of the Spokane River as the manifestations of the Evil Spirit, but the white men readily perceived their value for water power which is the present basis of the city's industrial strength. The growth was gradual until 1885 , which was the year of the discovery of the rich Coeur d'Alene mines a few miles to the eastward. Since the opening of these mines, the city's growth has been vigorous, even the disasterous fire of 1890 was only a momentary check, and the city in 1915 had an estimated population of 142,990 . Its rate of growth for the last decade is only slightly lower than that of Seattle. Spokane is a lumber center that draws its timber from the forests to the north and the east. It has many secondary industries that depend upon this lumber supply and cheap power. South and west of Spokane, the fertile and level lava plateau lands are the grain fields that supply the wheat for flour milling that ranks second in the industries of this "Minneapolis of the West." The industrial interests of which Spokane is a center are so different from those of the Puget Sound region that the state naturally divides into two political parties in direct response to these two physiographic regions that are respectively east and west of the Cascades. Spokane is the center of the Inland Empire and it is of interest to note in this connection that as late as 1907 it was seriously proposed to make this region a state, giving it the name of Lincoln.

\section{TACOMA}

Tacoma owes much to a group of railroad promoters who gave the city financial and transportation advantages as a stimulus to a growth that might have been greater had their sense of geographical location been keener. In 1873 this town of three hundred people was selected as the western terminus 
of the Northern Pacific Railroad. The railroad promoters purchased some three thousand acres of land and controlled nearly thirteen thousand acres of the surrounding land. The city was planned at the head of Commencement Bay; vast sums were spent in building depot, warehouses, docks, and repair shops. The city has had its most rapid growth since it has been reached by competing railroad and steamship lines. The city is on a peninsula standing between Commencement Bay and the Narrows of Puget Sound. Where the Puyallup River enters Commencement Bay in the northeastern part of the city, the present extensive shipping interests had their origin. The present harbor has fourteen miles of water front and the city handles about forty per cent of the import and export trade of Puget Sound. The chief industrial interests are lumbering, flour milling and meat packing. The city had an estimated population in 1915 of 108,094 .

\title{
INDUSTRIAL RESOURCES OF WASHINGTON
}

\author{
By H. K. Benson \\ Director of the Bureau of Industrial Research \\ University of Washington
}

\begin{abstract}
LTHOUGH the state of Washington has not developed a great manuA facturing industry it nevertheless possesses an abundance of raw materials and certain other advantages which are unique and which give promise of extensive development in the future. Combined with a wealth of natural resources, the state contains a variety of exceedingly valuable secondary conditions, such as the equable climate of the coast, great harbors constituting a gateway for commerce with Alaska and the Orient, a topography yielding enormous water power, together with great scenic beauty. It is of interest to consider these various factors as fields for possible development.
\end{abstract}

\section{Present Industrial Development}

According to the figures of the last census the various industries of the state produce commodities valued at over 330 million dollars annually. Of this amount about one-third consists of agricultural products distributed as follows:

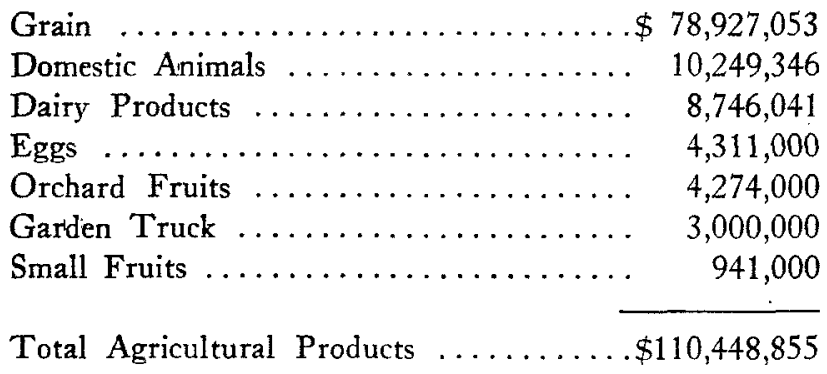

